\title{
[Regular Paper] \\ Effectiveness of Spiral Reactor for Biodiesel Production Using Supercritical t-Butyl Methyl Ether (MTBE)
}

\author{
Obie FAROBIE and Yukihiko MATSUMURA* \\ Div. of Energy and Environmental Engineering, Institute of Engineering, Hiroshima University, \\ 1-4-1 Kagamiyama, Higashi-Hiroshima, Hiroshima 739-8527, JAPAN
}

(Received October 5, 2014)

\begin{abstract}
A new approach to non-catalytic biodiesel production under supercritical conditions of $t$-butyl methyl ether (MTBE) using a novel spiral reactor is proposed. Previously, canola oil was reacted with MTBE under supercritical conditions to generate fatty acid methyl esters (FAME) and glycerol $t$-butyl ether (GTBE). To conduct this reaction more effectively, a novel spiral reactor that could also serve as heat exchanger was employed in this study. Using a pressure of $10 \mathrm{MPa}$ and an oil-to-MTBE molar ratio of $1: 40$, experiments were performed at $250-400{ }^{\circ} \mathrm{C}$ over 6-30 min. Complete conversion to FAME (FAME yield of $1.00 \mathrm{~mol} / \mathrm{mol}$ ) was rapidly achieved in $20 \mathrm{~min}$ at $385^{\circ} \mathrm{C}$. The results revealed that the spiral reactor is superior to a conventional reactor because of the improved FAME yield and thermal efficiency.
\end{abstract}

\section{Keywords \\ Biomass, Biodiesel, MTBE, Spiral reactor, Supercritical fluid}

\section{Introduction}

Recently, renewable energy sources have attracted enormous attention because of global warming, the ongoing depletion of fossil fuels, and environmental pollution issues. One promising renewable energy is biodiesel, which is defined by the American Society for Testing and Materials (ASTM) as monoalkyl esters of long chain fatty acids derived from renewable lipid feedstocks, which include vegetable oils ${ }^{1), 2)}$, animal fats $^{3)}$, waste cooking oils ${ }^{4), 5)}$, and microalgae ${ }^{6), 7)}$.

In our previous study, we proposed a novel biodiesel production method that used supercritical $t$-butyl methyl ether $(\mathrm{MTBE})^{8)}$. The products obtained from this transesterification process are fatty acid methyl esters (FAME) and glycerol $t$-butyl ether (GTBE). GTBE is a useful additive that can improve diesel fuel quality because of its high cetane number and good blending properties. It may also reduce the generation of carbon monoxide and particulate matter due to incomplete combustion because of its oxygenated structure ${ }^{9) \sim 11)}$.

In spite of these positive features, our biodiesel production method still has a problem associated with heat recovery. Because supercritical conditions require elevated temperatures and high pressures, large amounts

DOI: dx.doi.org/10.1627/jpi.58.110

* To whom correspondence should be addressed.

* E-mail: mat@hiroshima-u.ac.jp of heat must be added. This heat must be properly recovered if the overall process is to be energetically efficient. Without this heat recovery, $1.5 \mathrm{MJ}$ of heat is lost for production of $35 \mathrm{MJ}$ of FAME.

A spiral reactor that could also serve as a heat exchanger was found useful to circumvent this prob$\mathrm{lem}^{12)}$. This spiral reactor comprised a parallel-tube heat exchanger and transesterification reactor. The parallel tube heat exchanger, where heat is recovered, was made of stainless-steel tubing with the length of $2.5 \mathrm{~m}$. This heat exchanger part was composed of two tubes placed side-by-side in a spiral formation. Space between the tubes were filled with heat transfer cement for good heat transfer. Effective heat recovery from the high temperature reactor effluent to the low temperature inlet flow was achieved in counter-flow mode. Meanwhile, the reactor part, where the transesterification reaction mainly took place, was made of the same material as the heat exchanger, but the length is longer, i.e., $10 \mathrm{~m}$. This reactor part was designed as an insulated tubing for the high-temperature transesterification reaction to take place efficiently. It was reported that this spiral reactor was effective in the production of biodiesel using ethanol under supercritical conditions with the successful recovery of heat.

However, the reactor properties have not been well characterized. There are two expected advantages. First, part of the reaction can take place in the heating section, improving the FAME yield. Second, the heat 


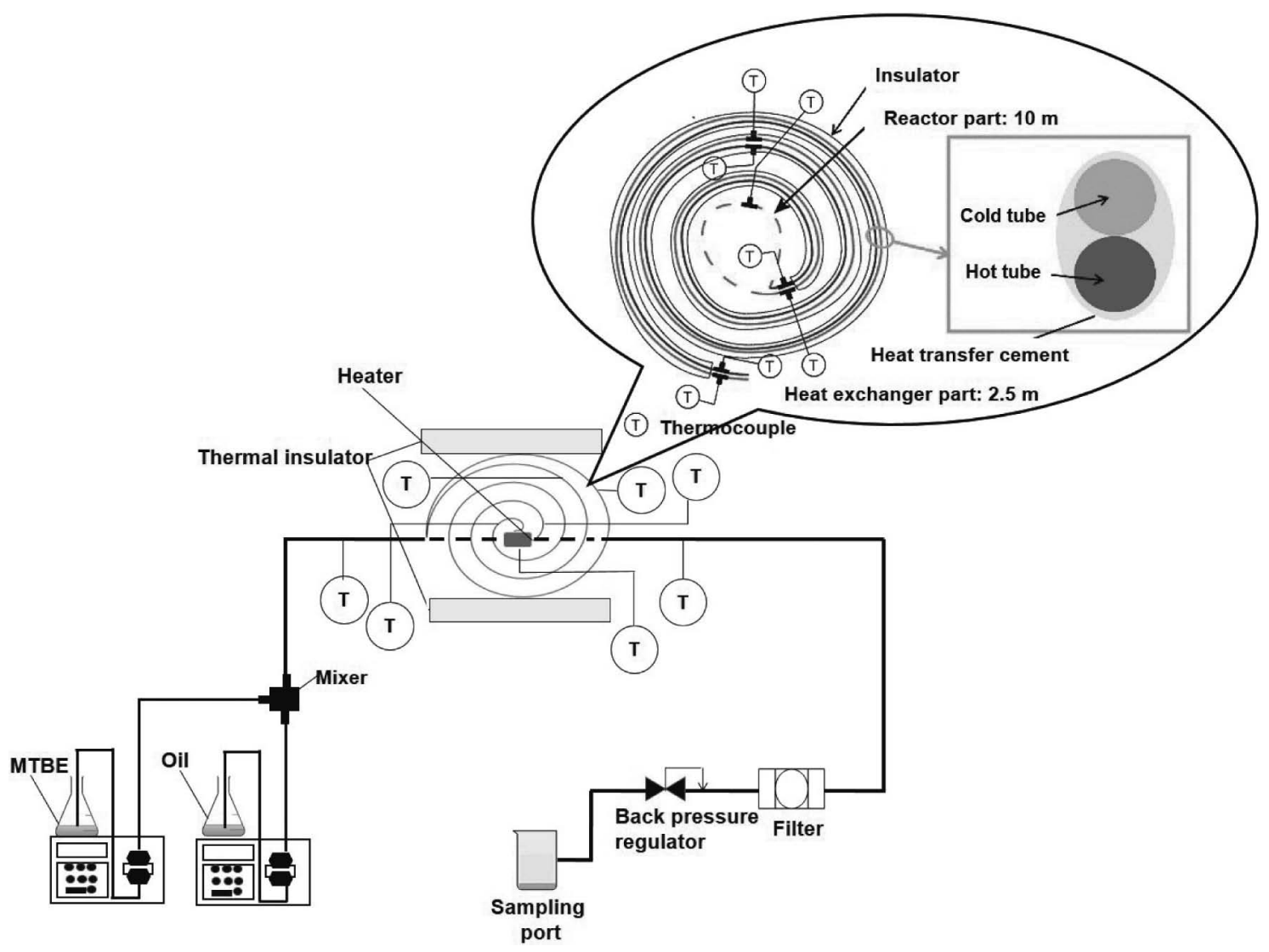

Fig. 1 Experimental Apparatus and a Detail Schematic of Spiral Reactor

needed to achieve reaction temperature can be effectively recovered. However, these effects have not been quantitatively evaluated. The purpose of this study was to examine the effectiveness of the spiral reactor on supercritical MTBE biodiesel production by elucidating the effects of temperature and reaction time on FAME yields.

\section{Materials and Methods}

\section{1. Experimental Apparatus and Procedure}

The experimental apparatus as well as a detailed schematic of the spiral reactor is schematically illustrated in Fig. 1. The apparatus consisted of a pump, the spiral reactor, a ceramic microheater, heat transfer cement, a thermal insulator, thermocouples, a filter, and a backpressure regulator.

The spiral reactor consisted of stainless-steel tubing (SS316) with an outer diameter of $3.17 \mathrm{~mm}$ and an inner diameter of $2.17 \mathrm{~mm}$. It comprised a heat exchanger and the reactor. The heat exchanger was a pair of tubes placed side-by-side and connected to each other. The reactor was a single tube that was thermally controlled by the electric heater. Thermocouples, connected with a tee union fitting, were used to measure temperatures inside the spiral reactor. The lengths of
Table 1 Experimental Conditions for Biodiesel Production in Supercritical MTBE Using Spiral Reactor

\begin{tabular}{ll}
\hline \multicolumn{1}{c}{ Types of condition } & \multicolumn{1}{c}{ Experimental range } \\
\hline Feedstock & Canola oil and MTBE \\
Reaction time & $6-30 \mathrm{~min}$ \\
Oil-to-MTBE molar ratio & $1: 40$ \\
Temperature & $250-400{ }^{\circ} \mathrm{C}$ \\
Pressure & $10 \mathrm{MPa}$ \\
Reactor type & Spiral reactor \\
Reactor length & $10 \mathrm{~m}$ \\
\hline
\end{tabular}

the reactor and the heat exchanger were $10.0 \mathrm{~m}$ and $2.5 \mathrm{~m}$, respectively.

A mixture of canola oil and MTBE was fed to the spiral reactor at the desired temperature. In this study, the transesterification reaction was carried out at $10 \mathrm{MPa}$ in the temperature range $250-400{ }^{\circ} \mathrm{C}$ with a fixed oil-to-MTBE molar ratio of $1: 40$. The reaction was performed over 6 to $30 \mathrm{~min}$, and samples were obtained after achieving a steady state. The obtained products were removed from the reactor after passing through the filter and back-pressure regulator. The experimental conditions are summarized in Table $\mathbf{1}$.

The residence time was determined using Eq. (1), assuming there is no volume change caused by mixing. 


$$
\begin{aligned}
& \text { (Residence time }[\min ])= \\
& \frac{\left(\text { Reactor volume }\left[\mathrm{dm}^{3}\right]\right)}{\frac{(\text { Mass flow rate of oil }[\mathrm{g} / \mathrm{min}])}{\left(\text { Density of oil }\left[\mathrm{g} / \mathrm{dm}^{3}\right]\right)}+\frac{(\text { Mass flow rate of MTBE }[\mathrm{g} / \mathrm{min}])}{\left(\text { Density of MTBE }\left[\mathrm{g} / \mathrm{dm}^{3}\right]\right)}}
\end{aligned}
$$

The product concentration was calculated using a calibration curve on the basis of peak area.

The thermal efficiency of the heat exchanger was calculated using Eq. (2).

$$
\text { (Thermal efficiency) }=\frac{T_{\infty 2, \mathrm{o}}-T_{\infty 2, \mathrm{i}}}{T_{\infty 1, \mathrm{i}}-T_{\infty 1, \mathrm{o}}}
$$

where $T_{\infty 1, \mathrm{i}}$ is the temperature of the hot flow at the inlet of the heat exchanger; $T_{\infty 1,0}$ is the temperature of the hot flow at the exit of the heat exchanger; $T_{\infty 2,0}$ is the temperature of the cold flow at the exit of the heat exchanger; and $T_{\infty 2, \mathrm{i}}$ is the temperature of the cold flow at the inlet of the heat exchanger.

\section{2. Analysis}

The products were analyzed by gas chromatography (GC-390B; GL Sciences) using a MET-Biodiesel column $(14 \mathrm{~m} \times 0.53 \mathrm{~mm} \times 0.16 \mu \mathrm{m}$ film thickness $)$ with an integrated $2 \mathrm{~m}$ guard column (Sigma Aldrich, 28668$\mathrm{U})$ and a flame-ionization detector (FID). Argon was used as the carrier gas. The temperature program began at $50{ }^{\circ} \mathrm{C}$. After holding for $1 \mathrm{~min}$, the temperature was raised at $15{ }^{\circ} \mathrm{C} / \mathrm{min}$ to $250{ }^{\circ} \mathrm{C}$ and held for $10 \mathrm{~min}$. Finally, the temperature was increased to $380{ }^{\circ} \mathrm{C}$ at $15^{\circ} \mathrm{C} / \mathrm{min}$ and kept at this temperature for $5 \mathrm{~min}$. The temperatures of the injector and detector were both set at $380{ }^{\circ} \mathrm{C}$. Both standard and sample injection volumes were $1 \mu \mathrm{L}$, and peak identification was carried out by the comparison of retention times between the standard and sample compounds. Tricaprin was used as an internal standard.

Experimental FAME yields were calculated by dividing the moles of FAME product by the moles of fatty acid groups in the initial triglyceride (TG), as shown in Eq. (3).

$$
(\text { Product yield })=\frac{(\text { Molar amount of product FAME })}{(\text { Molar amount of fatty acid group in initial TG })}
$$

\section{3. Reagents and Materials}

All reagents were used without further treatment. The canola oil feedstock was a commercial one produced by J-Oil Mills (Tokyo). MTBE was produced by Nacalai Tesque, Inc. (Kyoto). Fatty acid methyl ester standards (methyl oleate, methyl linoleate, methyl linolenate, methyl palmitate, and methyl stearate) were purchased from Tokyo Chemical Industry Co., Ltd. (TCI, Tokyo). Triolein, diolein, and monoolein standards were purchased from Nacalai Tesque, Inc., Sigma-Aldrich Co. (Japan), and TCI, respectively. The GTBE standard was purchased from SigmaAldrich Co. The reagents used for GC standard prep-

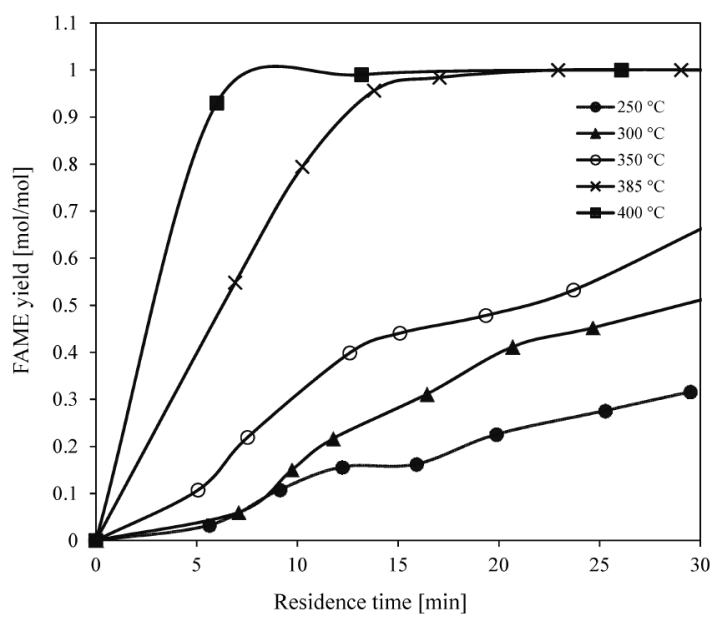

Fig. 2 Effect of Temperature on FAME Yield (experimental conditions: $10 \mathrm{MPa}$, oil-to-MTBE molar ratio of $1: 40$ )

aration (tricaprin and $n$-hexane) were analytical grade.

\section{Results and Discussion}

\section{1. Effect of Temperature on FAME Yield}

To investigate the characteristics of the spiral reactor, the effect of temperature on FAME yield was studied first. The transesterification of canola oil and MTBE was carried out in the temperature range $250-400{ }^{\circ} \mathrm{C}$ at a fixed oil-to-MTBE molar ratio of $1: 40$ and a pressure of $10 \mathrm{MPa}$. The change in FAME yield with temperature is shown in Fig. 2. As expected, an increase in the reaction temperature from 250 to $400{ }^{\circ} \mathrm{C}$ leads to an acceleration of the MTBE reactivity, affording higher FAME yields for the same residence time. Theoretically, higher reaction temperatures would result in higher reaction rates, which would consequently correspond to higher FAME yields for the same residence times. These results are in good agreement with previous reports of biodiesel production under supercritical conditions using methanol, ethanol, dimethyl carbonate, or methyl acetate. In supercritical methanol and ethanol, Rathore and Madras ${ }^{13)}$ reported that the conversion of oil to biodiesel increased as the temperature rose from 200 to $400{ }^{\circ} \mathrm{C}$. Ilham and Saka ${ }^{14)}$ also investigated the effect of temperature on FAME yield under supercritical dimethyl carbonate conditions. They observed that a temperature increase from 270 to $385{ }^{\circ} \mathrm{C}$ led to increased FAME yield at $10 \mathrm{MPa}$ over $20 \mathrm{~min}$. In supercritical methyl acetate, Goembira and Saka ${ }^{15)}$ found that the FAME yield increased with a temperature rise from 300 to $380{ }^{\circ} \mathrm{C}$ at $20 \mathrm{MPa}$ and an oil-to-methyl acetate molar ratio of $1: 42$.

\section{2. Effect of Reaction Time}

To further investigate the reaction characteristics, changes of conversion of the feedstock TG and yields of final product FAME and by-product GTBE with resi- 


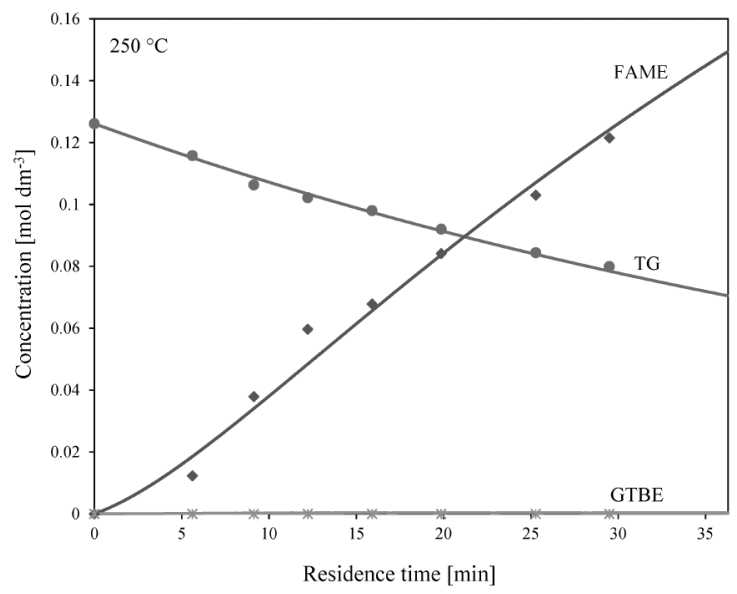

Fig. 3 Effect of Residence Time on FAME Concentration and Triglyceride Consumption (experimental conditions: $250{ }^{\circ} \mathrm{C}$, $10 \mathrm{MPa}$, oil-to-MTBE molar ratio of $1: 40$ )

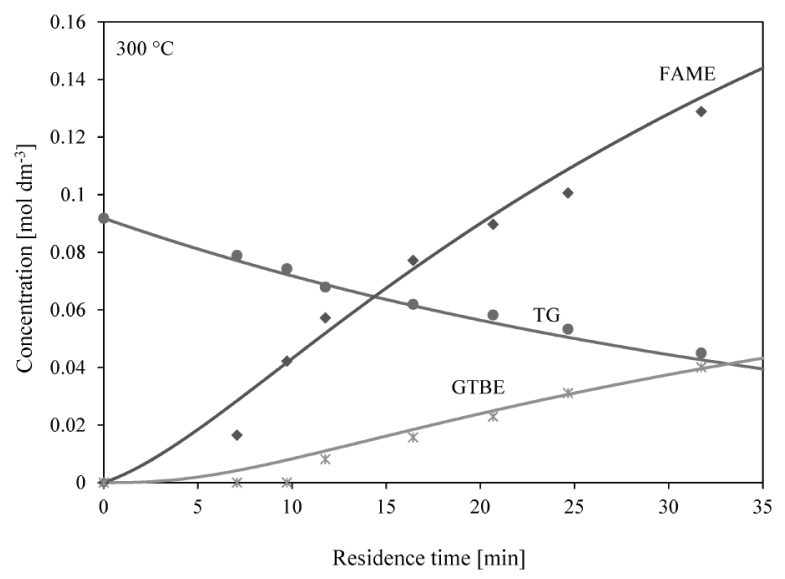

Fig. 4 Effect of Residence Time on FAME Concentration and Triglyceride Consumption (experimental conditions: $300{ }^{\circ} \mathrm{C}$, $10 \mathrm{MPa}$, oil-to-MTBE molar ratio of $1: 40$ )

dence time were measured at $250,300,350,385$, and $400{ }^{\circ} \mathrm{C}$. The results are shown in Figs. 3, 4, 5, 6, and 7 , respectively. Note that the unit for the yield in these figures is $\left[\mathrm{mol} \mathrm{dm}^{-3}\right]$, which is suitable for reaction rate analysis. Generally, in all cases, a longer reaction time resulted in a higher FAME yield. This may be attributed to the increase in contact time between the canola oil and the reactant when reaction times were extended.

At $250{ }^{\circ} \mathrm{C}$ and $300{ }^{\circ} \mathrm{C}$, the FAME yields were relatively low. In addition, although the GTBE by-product was not observed at $250{ }^{\circ} \mathrm{C}$, it was present above $300{ }^{\circ} \mathrm{C}$. At $350{ }^{\circ} \mathrm{C}$, the conversion of canola oil to FAME was higher than at $250{ }^{\circ} \mathrm{C}$ and $300{ }^{\circ} \mathrm{C}$, but it was still relatively low. Almost half of the TG was converted into FAME after $25 \mathrm{~min}$, resulting in a FAME yield of $0.53 \mathrm{~mol} / \mathrm{mol}$ (concentration of $0.1667 \mathrm{~mol} \mathrm{dm}^{-3}$ ).

At $385^{\circ} \mathrm{C}$, a substantial change in the conversion of canola oil to FAME was observed at a reaction time of

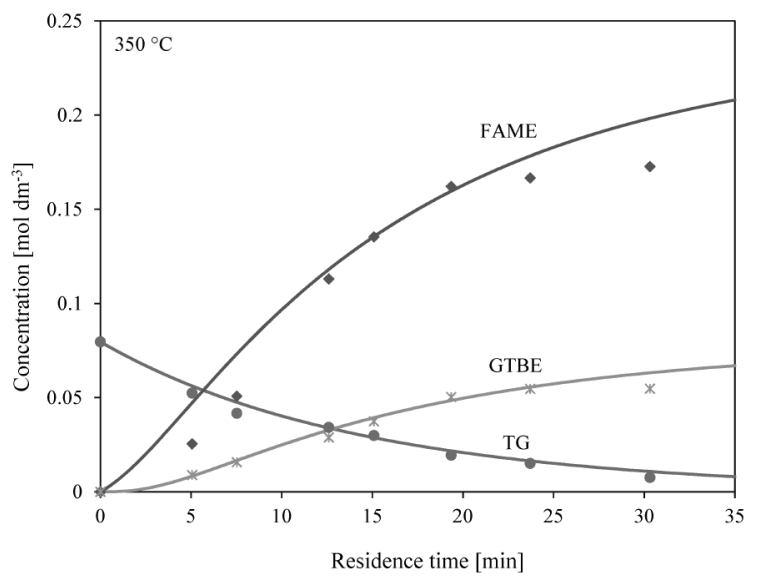

Fig. 5 Effect of Residence Time on FAME Concentration and Triglyceride Consumption (experimental conditions: $350{ }^{\circ} \mathrm{C}$, $10 \mathrm{MPa}$, oil-to-MTBE molar ratio of $1: 40$ )

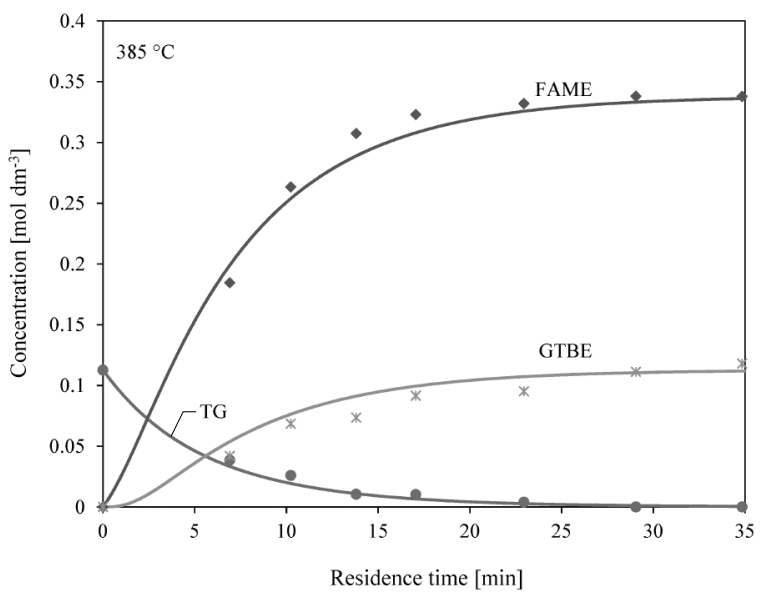

Fig. 6 Effect of Residence Time on FAME Concentration and Triglyceride Consumption (experimental conditions: $385{ }^{\circ} \mathrm{C}$, $10 \mathrm{MPa}$, oil-to-MTBE molar ratio of $1: 40$ )

$12 \mathrm{~min}$. FAME yields of about $0.95 \mathrm{~mol} / \mathrm{mol}$ and $0.98 \mathrm{~mol} / \mathrm{mol}$ (concentrations of $0.3074 \mathrm{~mol} \mathrm{dm}^{-3}$ and $0.3230 \mathrm{~mol} \mathrm{dm}^{-3}$ ) were obtained after transesterification reaction times of $12 \mathrm{~min}$ and $17 \mathrm{~min}$, respectively. Transesterification was almost complete within $20 \mathrm{~min}$, with almost all the canola oil converted to FAME. At $400{ }^{\circ} \mathrm{C}$, the FAME yield increased significantly in $12 \mathrm{~min}$; however, the yield was relatively constant thereafter.

The reaction temperature was found to directly affect the reaction rate of GTBE by-product formation. Overall, the GTBE yield increased with increasing temperature from 200 to $400{ }^{\circ} \mathrm{C}$. In addition, the consumption of TG was favored with increasing temperature, leading to higher FAME and GTBE yields, as expected.

\section{3. Comparison with Conventional Reactor}

The first expected advantage of the spiral reactor 


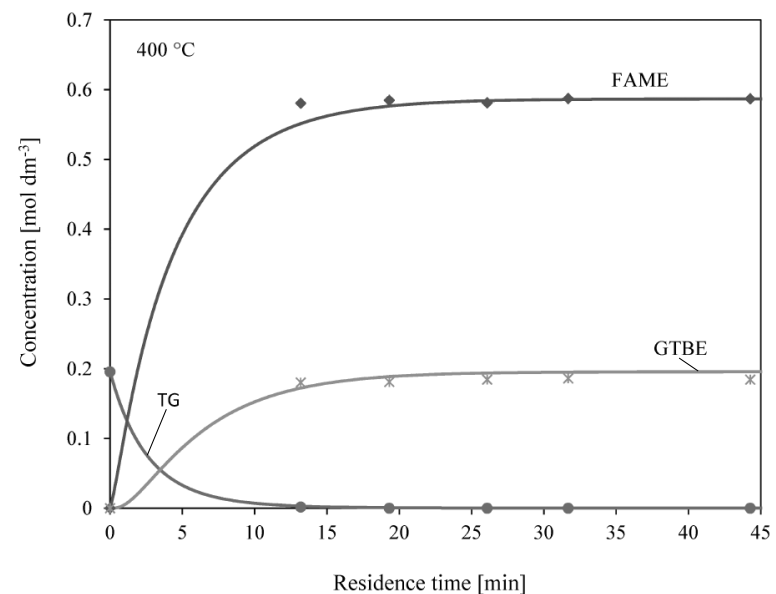

Fig. 7 Effect of Residence Time on FAME Concentration and Triglyceride Consumption (experimental conditions: $400{ }^{\circ} \mathrm{C}$, $10 \mathrm{MPa}$, oil-to-MTBE molar ratio of $1: 40$ )

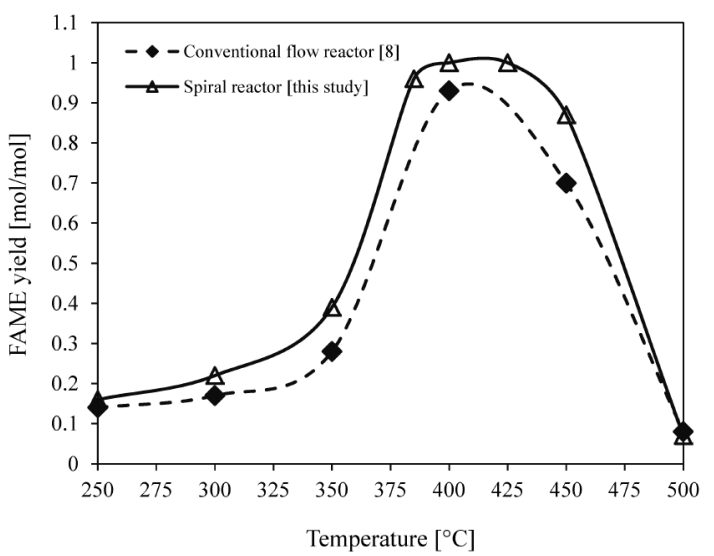

Fig. 8 The Comparison of FAME Yield for Conventional Flow and Spiral Reactors as a Function of Temperature (experimental conditions: $10 \mathrm{MPa}, 12 \mathrm{~min}$, oil-to-MTBE molar ratio of 1 : 40)

would be a higher yield as a result of the reaction in the heat exchanger. To verify this, we compared conventional flow and spiral reactors. The FAME yields for these reactors as a function of temperature are shown in Fig. 8. Note that the residence time in the conventional reactor was held equivalent to that in the reactor part of the spiral reactor. The figure shows that the spiral reactor produced a higher FAME yield compared to the conventional flow reactor, in part because a portion of the reaction takes place in the heat exchanger. The length of the heat exchanger is $2.5 \mathrm{~m}$ for the inlet flow side and $2.5 \mathrm{~m}$ for outlet flow side. Although the residence time at the reaction temperature is the same, the spiral reactor allows the reaction to also proceed while heating.

It should be noted that the decrease in FAME yield above $400{ }^{\circ} \mathrm{C}$ has been attributed to thermal decomposition. Niza et al. ${ }^{16)}$ found that the mono-unsaturated

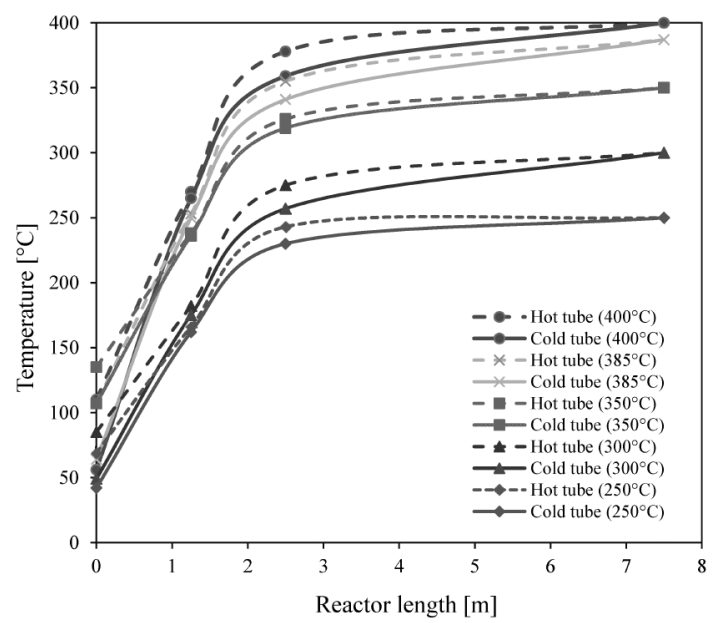

Fig. 9 Temperature Profile of Spiral Reactor

FAME produced under supercritical methyl acetate was relatively stable in the range $330-360{ }^{\circ} \mathrm{C}$, and prolonged exposure at those temperatures did not cause severe decomposition. However, significant degradation was clearly observed at $420{ }^{\circ} \mathrm{C}$. In addition, Imahara et $a l .{ }^{17)}$ observed that polyunsaturated FAMEs such as methyl linoleate (C18: 2) and methyl linolenate (C18: 3) were extensively decomposed at $350{ }^{\circ} \mathrm{C} / 43 \mathrm{MPa}$, and cis double bonds were isomerized into trans bonds. Moreover, He et al. $^{18)}$ found that the decrease in FAME yield for transesterification conducted in a continuous reactor was due to the reduction in unsaturated ester content caused by isomerization and thermal decomposition, especially for C18: 2 and C18: 3 . Lin et al. ${ }^{19)}$ studied the thermal decomposition mechanisms of biodiesel fuel, and identified processes involving isomerization, polymerization (Diels-Alder reaction), and pyrolysis which occurred in the ranges $275-400{ }^{\circ} \mathrm{C}$, $300-425{ }^{\circ} \mathrm{C}$, and $>350{ }^{\circ} \mathrm{C}$, respectively. These mechanisms also reduce the FAME yield in the spiral reactor, but the reaction in the heat exchanger helps to achieve higher FAME yields compared to the conventional reactor, especially in this high temperature range. The largest difference in FAME yield versus the conventional reactor, 0.17 , was obtained at $450{ }^{\circ} \mathrm{C}$. Thus, the advantage of a higher FAME yield due to the reaction in the heat exchanger has been confirmed experimentally.

\section{4. Heat Recovery Characteristics}

Another expected advantage of the spiral reactor would be heat recovery. Figure 9 shows the temperature profile at each position of the spiral reactor for the target temperatures $250-400{ }^{\circ} \mathrm{C}$. As shown, the oil and MTBE feedstocks were rapidly heated to the reaction temperature in the heat exchanger and maintained at that temperature in the reactor. Moreover, the temperatures of the hot and cold tubes were almost equal, indicating that heat recovery was occurring, as expected. The heat exchanger efficiencies, calculated using Eq. 


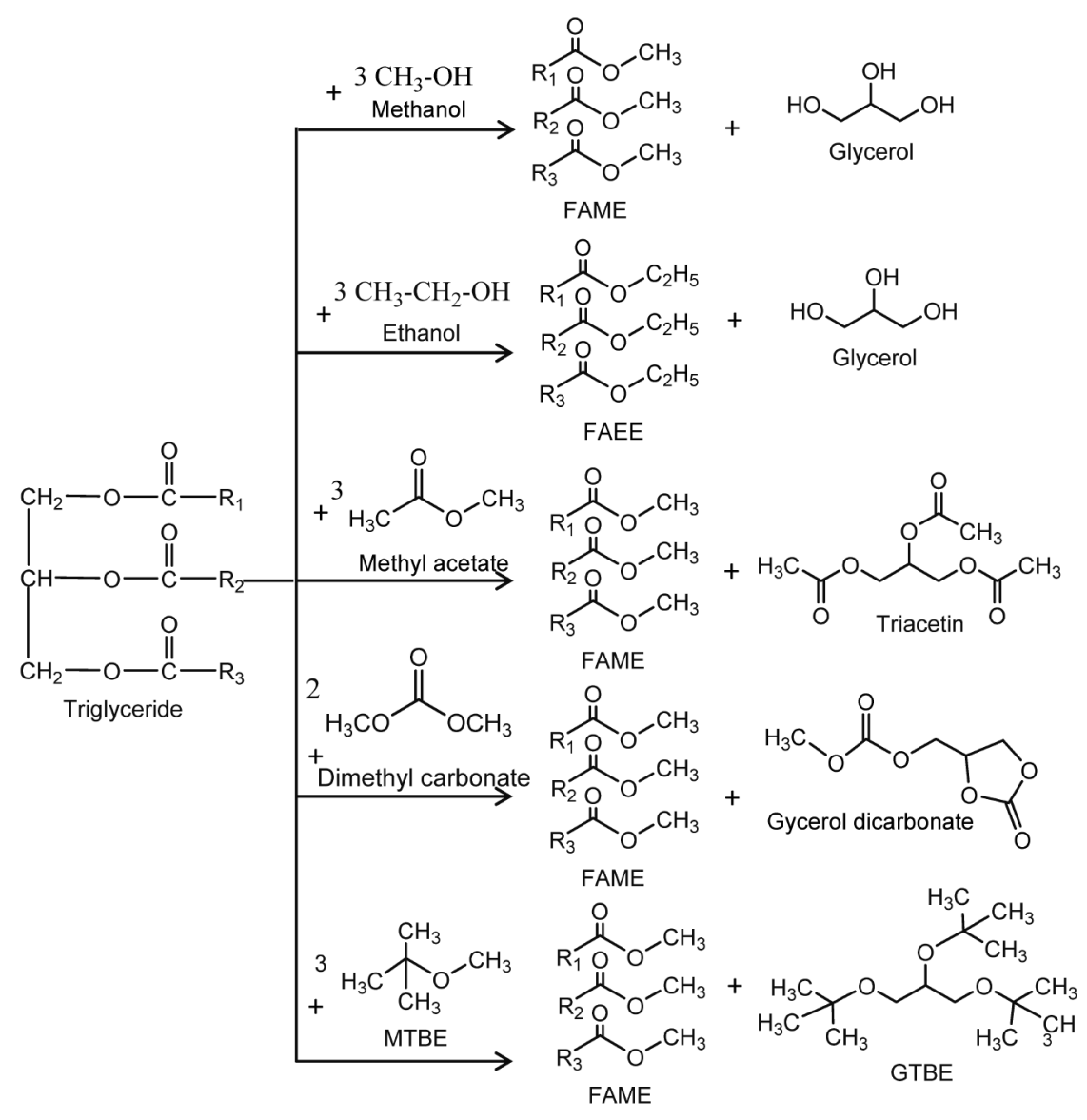

Fig. 10 The Chemical Reactions of Biodiesel Production under Supercritical Various Reactants

(2), were $0.92,0.91,0.90,0.89$, and 0.88 for the target temperatures of $250,300,350,385$, and $400{ }^{\circ} \mathrm{C}$, respectively.

\section{5. Comparison of Biodiesel Production with Previous Studies}

Finally, the FAME production characteristics of the spiral reactor were compared with previous reports of biodiesel production using supercritical alcohols. The pioneer researchers in biodiesel production conducted under supercritical conditions, Saka and Kusdiana ${ }^{20)}$, found that biodiesel can be synthesized by reacting rapeseed oil with methanol under supercritical conditions. In their process, FAME and glycerol were generated. Similarly, when ethanol was reacted with oil under supercritical conditions, the products consisted of fatty acid ethyl esters (FAEE) and glycerol. Other reactants that have the potential to react with oil to generate biodiesel and result in higher-value by-products are methyl acetate and dimethyl carbonate. The byproduct obtained from the transesterification of oil with methyl acetate is triacetin, whereas, the reaction with dimethyl carbonate generates glycerol carbonate as a by-product. Among the various alkyl groups that can replace the hydrogen atom in the hydroxyl group, the $t$-butyl group is very interesting. In this case, the prod- uct is GTBE, which is the reaction system employed here. For biodiesel production, the chemical reactions with various supercritical reactants are shown in Fig. 10.

Figure 11 compares the yields of biodiesel produced under the optimum conditions for supercritical methanol $\left(350{ }^{\circ} \mathrm{C} / 43 \mathrm{MPa}\right)^{20)}$, ethanol $\left(350{ }^{\circ} \mathrm{C} / 20 \mathrm{MPa}\right)^{21)}$, methyl acetate $\left.\left(350{ }^{\circ} \mathrm{C} / 17.8 \mathrm{MPa}\right)^{22}\right)$, dimethyl carbonate $\left(380{ }^{\circ} \mathrm{C} / 20 \mathrm{MPa}\right)^{23)}$, and $\mathrm{MTBE}\left(385^{\circ} \mathrm{C} / 10 \mathrm{MPa}\right)$ (this study). Note that weight percent unit is used here for the purpose of comparison. The increase in biodiesel yield obtained using supercritical methanol was almost the same as that obtained using supercritical dimethyl carbonate. The FAME yield obtained using supercritical MTBE was lower than those for supercritical methanol and dimethyl carbonate for the same reaction time, despite the higher temperature of the supercritical MTBE reaction. However, at a residence time of $15 \mathrm{~min}$, the yield of FAME from supercritical MTBE reached $98.3 \mathrm{wt} \%$, which is almost the same as those obtained using the supercritical methanol and dimethyl carbonate. In addition, it is interesting to note that the FAME yields for the supercritical MTBE are higher than those for the supercritical methyl acetate at the same reaction time. The higher reactivity of MTBE compared to methyl acetate could be attributed to the lower polarity 


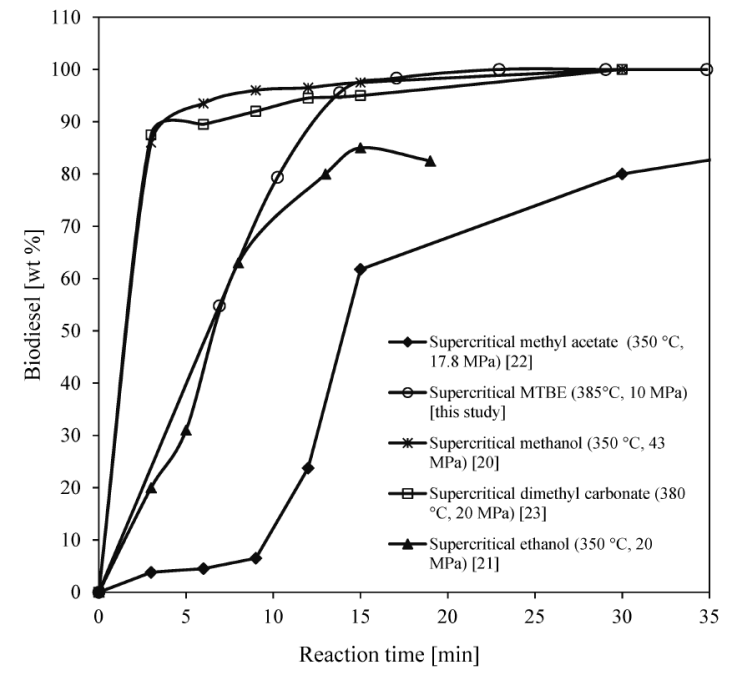

Fig. 11 Comparison of Biodiesel under Various Supercritical Reactants

of MTBE. Therefore, MTBE is more miscible with the oil at room temperature and pressure. Miscibility would be an advantage for MTBE by which to circumvent the mass transfer problem faced by more polar compounds.

\section{Conclusion}

In this study, a novel spiral reactor was employed for non-catalytic biodiesel production in supercritical MTBE. To investigate the characteristics of the spiral reactor, the effects of temperature and reaction time on FAME yield were studied. The FAME yields for conventional flow and spiral reactors as a function of temperature were also compared. The results showed that the spiral reactor performed well for biodiesel production, affording a higher FAME yield compared to the conventional flow reactor for the same residence time. This was partly a consequence of the portion of the reaction that takes place in the heat exchanger. In addition, the spiral reactor employed here was effective for biodiesel production using MTBE under high temperature and high pressure conditions because of the suc- cessful recovery of heat. The complete conversion of FAME $(1.00 \mathrm{~mol} / \mathrm{mol})$ was obtained after $20 \mathrm{~min}$ at $385{ }^{\circ} \mathrm{C}$ and an oil-to-MTBE molar ratio of $1: 40$ under a reactor pressure of $10 \mathrm{MPa}$.

\section{Acknowledgment}

OF would like to thank Japan Indonesia Presidential Scholarship (JIPS), the World Bank Institute for supporting his study in Japan.

\section{References}

1) Demirbas, A., Energy Convers. Manage., 44, 2093 (2003).

2) Xie, W., Zhao, L., Energy Convers. Manage., 79, 34 (2014).

3) Tashtoush, G. M., Al-Widyan, M. I., Al-Jarrah, M. M., Energy Convers. Manage., 45, 2697 (2004).

4) Abd Rabu, R., Janajreh, I., Honnery, D., Energy Convers. Manage., 65, 764 (2013).

5) Patle, D. S., Sharma, S., Ahmad, Z., Rangaiah, G. P., Energy Convers. Manage., 85, 361 (2014).

6) Demirbas, A., Demirbas, M. F., Energy Convers. Manage., 52, 163 (2011).

7) Wahidin, S., Idris, A., Shaleh, S. R. M., Energy Convers. Manage., 84, 227 (2014).

8) Farobie, O., Yanagida, T., Matsumura, Y., Fuel, 135, 172 (2014).

9) Kiatkittipong, W., Intaracharoena, P., Laosiripojan, N., Chaisuka, C., Praserthdam, P., Assabumrungrat, S., Comput. Chem. Eng., 35, 2034 (2011)

10) Klepáčová, K., Mravec, D., Kaszonyi, A., Bajus, M., Appl. Catal. A: General, 328, 1 (2007).

11) Frusteri, F., Arena, F., Bonura, G., Cannilla, C., Spadaro, L., Di Blasi, O., Appl. Catal. A: General, 367, 77 (2009).

12) Sasanami, K., Farobie, O., Matsumura, Y., 1st Asian Conference on Biomass Science (ACBS2014), Jan. 14, 2014, Kochi, Japan, P19.

13) Rathore, V., Madras, G., Fuel, 86, 2650 (2007).

14) Ilham, Z., Saka, S., Fuel, 97, 670 (2012).

15) Goembira, F., Saka, S., Bioresour. Technol., 131, 47 (2013).

16) Niza, N. M., Tan, K. T., Lee, K. T., Ahmad, Z., Appl. Energy, 101, 198 (2013).

17) Imahara, H., Minami, E., Hari, S., Saka, S., Fuel, 87, 1 (2008).

18) He, H., Wang, T., Zhu, S., Fuel, 86, 442 (2007).

19) Lin, R., Zhu, Y., Tavlarides, L. L., Fuel, 106, 593 (2013).

20) Saka, S., Kusdiana, D., Fuel, 80, 225 (2001).

21) Silva, C., Weschenfelder, T. A., Rovani, S., Corazza, F. C., Corazza, M. L., Dariva, C., Oliveira, J. V., Ind. Eng. Chem. Res., 46, 5304 (2007).

22) Goembira, F., Matsuura, K., Saka, S., Fuel, 97, 373 (2012).

23) Ilham, Z., Saka, S., Bioresour. Technol., 100, 1793 (2009). 
要旨

\section{超臨界メチルターシャリーブチルエーテル（MTBE）を用いた \\ バイオディーゼル生産のためのスパイラル反応器の有効性}

Obie FAROBIE，松村 幸彦

広島大学大学院工学研究院エネルギー・環境部門, 739-8527 広島県東広島市鏡山1-4-1

新規なスパイラル反応器を用いて, 超臨界メチルターシャ リーブチルエーテル（MTBE）条件下で触媒を用いない新たな バイオディーゼル生産法を提案した。これまで, 脂肪酸メチル エステル (FAME) とターシャリーブトキシグリセリン (GTBE) を生成するために, キャノーラ油は超臨界条件下でMTBE と 反応させていた。この反応をより効果的に行うために, 本研究 では熱交換器の役割も果たせる新規のスパイラル反応器を作製

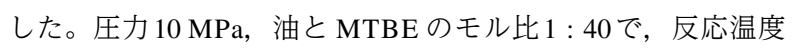
$250 \sim 400{ }^{\circ} \mathrm{C}$, 反応時間 6 30 min で実験を行った。FAMEへ の完全な転換（1.00 mol $/ \mathrm{mol}$ の FAME 収率）は $385^{\circ} \mathrm{C}, 20 \mathrm{~min}$ で達成された。この結果から, FAME 収率および熱効率が向上 したため, スパイラル反応器は従来の反応器と比べて優れてい ることが明らかになった。 